\title{
Human Values and Bullying: Do Age and Gender Moderate this Relationship?
}

\author{
Renan Pereira Monteiro \\ Universidade Federal do Piauí, Parnaíba, PI, Brasil \\ Emerson Diógenes de Medeiros \\ Universidade Federal do Piauí, Parnaiba, PI, Brazil \\ Carlos Eduardo Pimentel \\ Universidade Federal da Paraíba, João Pessoa, PB, Brazil \\ Ana Karla Silva Soares \\ Universidade Federal do Mato Grosso do Sul, Campo Grande, MS, Brazil \\ Hermógenes Acácio de Medeiros \\ Secretaria Municipal de Saúde de João Pessoa, PB, Brazil \\ Valdiney Veloso Gouveia ${ }^{1}$ \\ Universidade Federal da Paraíba, João Pessoa, PB, Brazil
}

\begin{abstract}
The serious consequences that underlie bullying are noticeable and it is important to know the variables that can predict this behavior pattern among students. The aim of the study was to understand to what extent human values predict bullying, testing the moderating role of gender and age. Participants were 300 children $(M=11.07 ; S D=1.31)$ from public and private schools, who answered the Bullying Behaviors Scale, the children version of Basic Values Survey and demographic questions. Results showed that values from the interactive $(\beta=-.21, \mathrm{~B}=-.14$, IC95\% $=-.23 /-.06, p<.001)$ and promotion $(\beta=.32, \mathrm{~B}=.14, \mathrm{IC} 95 \%=.09 / .20, p<.001)$ subfunctions predict bullying behavior. We found that these relationships were not moderated by the children's gender or age. It may be concluded that human values are an important variable to understand this aggressive behavior among peers, promoting interventions that may reduce the problem at schools.
\end{abstract}

Keywords: Bullying, human values, children, school.

\section{Valores Humanos e Bullying: Idade e Sexo Moderam essa Relação?}

\section{Resumo}

São perceptíveis as consequências graves que perpassam o bullying, sendo importante conhecer variáveis que possam predizer este padrão de comportamento entre escolares. O presente estudo objetivou conhecer em que medida os valores humanos predizem o bullying, testando o papel moderador das variáveis

Mailing address: Universidade Federal da Paraíba, Centro de Ciências Humanas, Letras e Artes, Departamento de Psicologia, João Pessoa, PB, Brazil 58.051-900. Phone: + 55(83)32167856; Fax: +55(83)32167064. E-mail: vvgouveia@gmail.com

Agradecimentos: Agradecemos à Coordenação de Aperfeiçoamento de Pessoal de Nível Superior (CAPES) e ao Conselho Nacional de Desenvolvimento Científico e Tecnológico (CNPq) em razão de bolsas concedidas ao primeiro (Doutorado em Psicologia Social) e último (Produtividade em Pesquisa) autores. 
sexo e idade. Participaram 300 crianças $(M=11,07 ; D P=1,31)$ de escolas públicas e particulares, as quais responderam a Escala de Comportamentos de Bullying, o Questionário dos Valores Básicos - Infantil e perguntas demográficas. Os resultados indicaram que os valores das subfunções interativa ( $\beta=$ $-0,21, \mathrm{~B}=-0,14, \mathrm{IC} 95 \%=-0,23 /-0,06, p<0,001)$ e realização $(\beta=0,32, \mathrm{~B}=0,14, \mathrm{IC} 95 \%=0,09 / 0,20$, $p<0,001)$ predisseram comportamentos de bullying. Posteriormente, verificou-se que estas relações não foram moderadas por sexo e idade das crianças. Conclui-se que os valores humanos são uma variável importante para compreender este tipo de comportamento agressivo entre pares, favorecendo intervenções que venham a reduzir este problema nas escolas.

Palavras-chave: Bullying, valores humanos, crianças, escola.

\section{Los Valores Humanos y el Bullying: La Edad y el Género Moderan esta Relación?}

\section{Resumen}

Son perceptibles las graves consecuencias que perpasan el bullying, siendo importante conocer variables que puedan predecir este comportamiento entre estudiantes. El presente trabajo tuvo como objetivo conocer en que grado los valores humanos predicen el bullying, evaluando el papel moderador de las variables género y edad. Participaron 300 niños $(M=11.07 ; S D=1.31)$ de escuelas publicas y privadas, los cuales responderon la Escala de Comportamentos de Bullying, el Cuestionario de Valores Básicos Infantil y preguntas demográficas. Los resultados indicaron que los valores de las subfunciones interactiva $(\beta=-.21, \mathrm{~B}=-.14, \mathrm{IC} 95 \%=-.23 /-.06, p<.001)$ y realización $(\beta=.32, \mathrm{~B}=.14$, IC95\% $=.09 / .20$, $p<.001$ ), predicieron comportamientos de bullying. Posteriormente, se verificó que estas relaciones no fueron moderadas por género y edad de los niños. Se concluye que los valores humanos son una variable importante para comprender este tipo de comportamiento, favorecendo intervenciones que vengan a reducir este problema en las escuelas.

Palabras clave: Bullying, valores humanos, niños, escuela.

Engaging in episodes of bullying can result in severe problems such as suicidal thoughts, substance use and violent retaliation from victims (Geel, Vedder, \& Tanilon, 2014; Reed, Nugent, \& Cooper, 2015; Roh et al., 2015). Despite these consequences, bullying reports have been increasing in school environments, showing that this type of aggression among peers is becoming a public health problem (Craig et al., 2009; Hertz, Donato, \& Wright, 2013; Kim Koh, \& Leventhal, 2005). Therefore, it is imperative to understand its background.

Conceptually, bullying appears as a subtype of aggressive behavior, which is practiced repeatedly and without justification, physical, verbal and/or psychological abuse, in which the victim is in an unequal power relation, making it impossible to defend herself (Baldry \& Farrington, 2000; Olweus, 1993; Salmivalli, 2010;
Smith \& Morita, 1999). The intention of the bully and the asymmetry of power between the bully and victim are core attributes of the phenomenon (Farrington, 1993).

Although the literature presents definitions and specific ways to estimate bullying, the identification of the corresponding behavior by parents, guardians and professionals is still deficient. In fact, these agents commonly characterize the aggression suffered by victims as part of the socialization process, i.e., the problem is seen as something natural (Blank \& Liberal, 2005; Lopes, 2005). The naturalization of the phenomenon contrasts with its severe health implications.

Considering the above-mentioned, it must be said that among the participants of bullying, bullies tend to exhibit an antisocial behavior such as the use of licit or illicit drugs, as well as 
being people who might be potentially in conflict with the law (Bender \& Lösel, 2011; Farrington $\&$ Ttofi, 2011; Oliveira et al., 2016); the victims are likely to be dissatisfied with their life and show depressive and suicidal tendencies (Costa, Xavier Andrade, Proietti, \& Caiaffa, 2015; Fleming \& Jacobsen, 2009; Geel et al., 2014;. Klomek, Sourander, \& Gould, 2010; Roh et al., 2015); victims/bullies tend to have low levels of prosocial behavior, with frequent academic difficulties and the predisposition to the development of psychiatric disorders (Arseneault et al., 2006; Kim et al., 2005, Perren \& Alsaker, 2006; Sourander et al., 2007). The effects of bullying on the witnesses vary according to their involvement; for example, they may range from the extinction of behaviors related to solidarity and cooperation to suffering experienced by those who identify themselves with the victim (Ribeiro, 2007).

It is clear therefore, that participating in bullying behaviors can harm those involved, pointing to the need to understand the variables that can predict them. In fact, some studies have identified variables that may explain the willingness to engage in bullying as a bully (e.g. aggressiveness, anger, low agreeableness and low self-control) and victim (e.g., negative beliefs about herself, low social skills, social isolation and negative school climate; Cook, Williams, War, Kim, \& Sadek, 2010; Fossati, Borroni, \& Maffei, 2012; Lucia, 2016; Melander, Hartshorn, \& Whitbeck, 2013; Salmivalli, 2010; Tani, Greenman, Schneider, \& Fregoso, 2003).

Thus, studies have been taking into account a myriad of variables to understand the predisposition of children and adolescents to becoming bullies or victims of bullying, which is not limited to individual characteristics such as personality traits, but taking into account the importance of the context for the practice and development of bullying (Bowes et al., 2009; Lam, Law, Chan, Wong, \& Zhang, 2014; Lee, 2009). Furthermore, it is estimated that the gender and age of the students are individual characteristics that can influence the involvement in episodes of bullying (Lee, 2009).
There is a prevalence of men in both the victim and bully category (Carlyle \& Steinman, 2007; Lucia, 2016; Malta et al., 2014; Sourander, Hestelä, Helenius, \& Piha, 2000). For example, Malta et al. $(N=109,104$ Brazilian students) found that $7.9 \%$ of men and $6.5 \%$ of women were involved in bullying as victims, while $26.1 \%$ of men and $16 \%$ of women were bullies. It is noteworthy that the intensity of bullying may vary according to the age of the school children, but it reaches a peak in early adolescence due to the search for popularity when bullying can be used to enhance or increase one's status (LaFontana \& Cillessen, 2010). In a systematic review, Álvarez-García, Garcia and Nuñez (2015) observed that the practice of bullying and age have a pattern of curvilinear correlations (i.e., the probability of practicing bullying increases up to the age of 14 and the likelihood of aggression decreases after that). Therefore, demographic variables may be important for understanding bullying and its interaction can change the relations between the predictor variable and bullying behaviors.

Given the above, it seems pertinent to understand potential predictors of involvement in bullying behavior, whether in the role of the bully or victim. Nevertheless, it is noteworthy that the focus of the present study is on bullies. Studies have shown that this group presents empathic deficiencies, poor academic performance, negative evaluation of the school environment, and suffers multiple forms of domestic violence (Del Rey et al., 2016; Lucas, Jernbro, Tindberg, \& Janson, 2015; Nansel et al., 2001). In addition, practicing bullying in childhood is related to serious problems in adulthood, such as antisocial personality, substance abuse, anxiety disorders and depression (Sourander et al., 2007).

Therefore, understanding the factors related to bullying allows the early identification of children more likely to bully their peers. This aspect is important as it helps design interventions that focus on reducing bullying, fostering a school environment conducive to learning, and preventing future criminal behavior (practicing bullying in childhood is a predictor of delinquency in 
adulthood; Álvarez-García et al., 2015; Bender \& Lösel, 2011).

Among the psychological nature of variables, human values can contribute to the explanation of this type of aggression among peers. These have a strong social component, emphasizing the centrality of socialization in the process of its transmission, which is an important issue to take into account when studying bullying as the influence of family and peers may encourage the practice of these antisocial behaviors (Knafo, 2003; Ribeiro, 2007). Therefore, considering that the socialized values in certain contexts can help explain the practice of bullying, our next section will discuss the relationship between two constructs.

\section{Values and Bullying}

The conception of human values adopted in the present study derives from the Functional theory (Gouveia, 2013; Gouveia, Milfont, \& Guerra, 2014), an individual perspective that considers the values are psychological aspects that has two functions: guiding actions and expressing needs. The six subfunctions are derived from the intersection of functions, as described below, indicating three specific values, between parentheses, that represent them.

Excitement subfunction (emotion, pleasure and sexuality). These values describe people driven by the search for sensations; the values promote ease of change and innovation in social structures.

Promotion subfunction (success, power and prestige). Typical values of people seeking material achievement, seeking for practical behaviors and decisions and aiming for personal success.

Existence subfunction (personal stability, health and survival). The main purpose of these values is to ensure the basic conditions for biological and psychological survival of the individual, compatible with the pursuit of personal and social values.

Suprapersonal subfunction (beauty, knowledge and maturity). These values represent aesthetic needs of cognition and self-realization, reflecting a mature understanding of life and emphasizing the relevance of general and abstract principles, consistent with personal and social orientations.

Interactive subfunction (affectivity, social support and belonging). These values represent needs of belonging, love and affiliation, providing the establishment and maintenance of interpersonal relations by the person who prioritizes the others.

Normative subfunction (obedience, religiosity and tradition). These values reflect the importance of preserving culture and social norms in which obedience is valued above all, highlighting the social hierarchy as a guiding principle.

Considering the description of these subfunctions and the evidence that indicates that bullying is associated with high status and dominance of peers (Pouwels, Lansu, \& Cillessen, 2016; Salmivalli, 2010), it is possible to hypothesize that those involved in bullying behaviors as bullies prioritize promotion values, as these characterize people who seek power and recognition and may use aggression as a means to achieve leadership positions (Benish-Weisman, 2015; LaFontana \& Cillessen, 2010; Schumann, Craig, \& Rosu, 2014). On the other hand, social values, particularly the interactive subfunction, describe people driven by social interests who value the establishment of lasting emotional bonds, which can be a protective factor against bullying (Gouveia, 2013).

In fact, these presumptive associations were found in studies using the Schwartz model (1992) in which a positive correlation of aggressive behavior among peers and self-enhancement values (power and achievement) were found; and negative correlation with self-transcendence (universalism and benevolence), which describes those who care about the well-being and interest of others (Benish-Weisman, 2015; Knafo, 2003; Knafo, Daniel, \& Khoury-Kassabri, 2008; Menesini, Nocetini, \& Camodeca, 2013).

In short, the aim of this study was to understand the predictive role of values, from a functional perspective, regarding the bullying behavior and to verify to what extent gender and age of the bully may moderate the relationship. Specifically, two hypotheses were drawn from the literature: 
1. The scores of promotion values of participants are positively correlated with the scores in bullying measure and

2. Those values in the interactive subfunction will do inversely with this type of aggressive behavior.

It is clear that the relationship between values and bullying may be moderated by demographic variables, such as age and gender, which, in the case of human values, seem to have different effects (Feather, 2004; Gouveia, Vione, Milfont, \& Fischer, 2015), which may explain the practice of bullying. For example, since men prioritize promotion values more than women and have a more instrumental aggressive behavior, such as bullying (e.g., hitting, humiliating, kicking; Wang, Iannotti, \& Nansel, 2009), this behavior would most likely be more probable among them. On the other hand, as women score more than men in interactive values and are less prone to instrumental aggressive behavior than men, maybe they engage less in bullying. Nevertheless, due to the scarcity of studies on these presumptive moderations, we decided not to formulate any hypothesis regarding it.

\section{Method}

\section{Participants}

Three hundred students from the city of Parnaíba (PI), with ages ranging from 8 to 17 years $(M=11.07, S D=1.31)$, mostly women $(53.1 \%)$ and from private schools $(50.5 \%)$, participated in the study. This was a convenience sample (non-probabilistic), and those who participated, when present in the classroom and inquired to participate, agreed to participate voluntarily. It is noteworthy that $15.8 \%$ of respondents admitted to committing bullying while $25.3 \%$ said they were victims of aggression.

\section{Instruments}

The participants answered a series of questions and demographic questions at the end of the instrument (age, gender, and type of school). The instruments were as follows:

Bullying Behavior Scale (BBS; Medeiros, Gouveia et al., 2015). The instrument consists of
16 five-point items $(0=$ not once to $4=$ four or more times per week). These items are answered in view of the following stimulus sentence: "At my school, lately, I have presented such a behavior toward my colleagues". The instrument combines four factors, corresponding to the types of expression of the phenomenon: physical bullying (e.g., I kicked colleagues), verbal bullying (e.g., I nicknamed colleagues), relational bullying (e.g., I excluded and/or persuaded friends to exclude other colleagues) and cyberbullying (e.g., I posted photos on the Internet to ridicule colleagues). In the present study a satisfactory factorial structure was found $(\mathrm{CFI}=0.93$; $\mathrm{TLI}=$ 0.92 ; RMSEA $=0.02$ ), with an index for internal consistency $(\alpha)$ ranging from 0.64 (relational bullying) to 0.82 (cyberbullying).

Children Version of Basic Values Survey (QVB-I; Gouveia, Milfont, Soares, Andrade, \& Leite, 2011). The instrument consists of 18 items or specific values adapted for children (e.g., Power: being the boss or leader of the group of friends; bossing peers, and having power to decide things; Belonging: living well with family and neighbors; having friends at school or in the neighborhood; and participating in activities and playing with friends. The items are answered on a five-point scale $(1=$ not important to $5=$ maximum importance) and distributed over six factors. On this occasion, the factorial structure showed adequate fit indexes (CFI $=0.96$; TLI $=$ 0.95 , RMSEA $=0.04$ ), and the following Cronbach's alpha coefficients were found: excitement $(\alpha=0.55)$, promotion $(\alpha=0.59)$, existence $(\alpha=$ $0.48)$, supra-personal $(\alpha=0.40)$, interactive ( $\alpha=$ $0.51)$ and normative $(\alpha=0.51)$.

\section{Procedure}

After favorable report from the Research Ethics Committee of the Federal University of Piauí (CAAE: 0193.0.045.000-11), we contacted those responsible for the educational institutions to request permission to carry out the data collection. Because it is a sample of children, after the school directors granted permission, a term of responsibility was sent to the parents or guardians, who agreed their children could participate in the study, expressing their consent. 
Data collection was carried out in a collective environment (classroom), but the questionnaires were answered individually. At the time of collection, two researchers, who were able to answer any questions regarding the instruments, were present. It is noteworthy that all were informed that the study was anonymous and voluntary and the participant could withdraw at any time. On average, it took 30 minutes to complete the study.

\section{Data Analysis}

Data were analyzed using the statistical package SPSS (version 18) and R (R Core Team, 2015). The first software calculated descriptive statistics, Pearson correlation analysis, and multiple regression analysis to verify to what extent the values were related and could predict bullying behaviors; hierarchical regression analysis was applied to test the moderating role of gender and age of the participants.

The adequacy of the measures was verified with the R package lavaan (Rosseel, 2012), using the mean and variance adjusted least squares estimator (WLSMV), considering the following fit indexes: Comparative Fit Index (CFI), TuckerLewis Index (TLI) and Root Mean-Square Error of Approximation (RMSEA). To consider the model acceptable, CFI and TLI values should be above 0.90 , preferably above 0.95 (Kline, 2016) and RMSEA below 0.08 (Brown, 2006; Kline, 2016).

\section{Results}

Initially, Pearson's correlations were calculated to know to what extent and direction the six subfunctions would correlate with types of bullying behavior and their total score (Table 1). Assessing the pattern of correlations $(p<.05)$, we found that the promotion values positively correlated with the four types of bullying, while the interactive subfunction was negatively correlated to the three types of bullying behavior (physical, relational and cyberbullying). In addition to these subfunctions, the supra-personal subfunction, which, as the previous one, represents a humanitarian and idealistic motivation, was also inversely correlated with two dimensions of bullying measure (relational and cyberbullying). The BBS total score was correlated with the promotion $(r=0.28 ; p<.01)$, interactive $(r=-0.14 ; p<.01)$ and supra-personal subfunctions $(r=-0.12 ; p<.05)$.

The next step was the multiple regression analysis (stepwise method) and we found that the subfunctions of values could predict bullying behaviors. The total BBS score was considered as a criterion variable for the specific dimensions of bullying behaviors if consistently correlated with promotion and interactive subfunctions, as hypothesized, and these bullying factors were interrelated, justifying the compute of a general factor. The results reinforced the predictive role of the promotion $(\beta=0.32, \mathrm{~B}=0.14,95 \% \mathrm{CI}=$ $0.09 / 0.20, p<.001)$ and interactive values $(\beta=$ $-0.21, \mathrm{~B}=-0.14,95 \% \mathrm{CI}=-0.23 /-.06, p<.001)$. These two subfunctions showed $R=0.37$, together explaining $14 \%\left(R^{2}\right)$ of the variance of scores of the bullying measure $(p<.001)$.

Subsequently, hierarchical regression analysis was carried out to verify if gender and age would moderate the above-mentioned relations (values predicting bullying; Table 1). Initially, following the procedure described by Miles and Shevlin (2001) for continuous predictors, the promotion variable and age were standardized $(z)$, multiplying the two, thereby calculating the interaction term. Then the promotion subfunction and age standardized were considered in the first step of hierarchical regression, introducing the interaction between them in the second step of the analysis. There was no significant prediction of the interaction term, discarding possible moderation. We further tested if age would moderate the relationship between the interactive subfunction and bullying behavior, following the procedure described above. In this case, only the interactive subfunction predicted bullying behaviors, but not the interaction term. Thus, it was not considered the moderator role of age.

We sought to determine whether gender would moderate the relationship between the promotion subfunction and bullying behaviors. According the procedure of Miles and Shevlin (2001) for a continuous predictor and a cat- 
Table 1

Correlations and Hierachical Regression of Values Subfunctions and Bullying Factors

\begin{tabular}{|c|c|c|c|c|c|c|}
\hline \multirow{2}{*}{$\frac{\text { Correlations }}{\text { Human values }}$} & \multicolumn{6}{|c|}{ Bullying behaviors } \\
\hline & Total & Physical & Verbal & Relationa & & yberbullying \\
\hline Excitement & -0.02 & -0.03 & 0.01 & -0.03 & & -0.06 \\
\hline Promotion & $0.28 * *$ & $0.18 * *$ & $0.21 * *$ & $0.25 * *$ & & $0.12^{*}$ \\
\hline Suprapersonal & $-0.12 *$ & -0.09 & -0.08 & $-0.11 *$ & & $-0.13 *$ \\
\hline Existence & -0.08 & -0.04 & 0.01 & -0.06 & & $-0.12 *$ \\
\hline Interactive & $-0.16^{* *}$ & $-0.14 * *$ & -0.08 & $-0.15^{* *}$ & & $-0.14 * *$ \\
\hline Normative & -0.07 & -0.05 & -0.06 & -0.03 & & -0.09 \\
\hline \multicolumn{7}{|l|}{ Regressions } \\
\hline Promotion x Age & $\beta$ & $t$ & \multicolumn{2}{|c|}{ Interactive x Age } & $\beta$ & $t$ \\
\hline zPromotion & $0.28 * *$ & 4.53 & \multicolumn{2}{|l|}{ zInteractive } & $-0.18 * *$ & -2.86 \\
\hline zAge & -0.03 & -0.54 & \multicolumn{2}{|l|}{ zAge } & -0.04 & -0.60 \\
\hline Interaction & -0.01 & -0.14 & \multicolumn{2}{|l|}{ Interaction } & 0.04 & 0.64 \\
\hline Promotion x Gender & \multicolumn{6}{|c|}{ Interactive $\mathrm{x}$ Gender } \\
\hline C_Promotion & 0.34 & 1.65 & \multicolumn{2}{|c|}{ C_Interactive } & -0.06 & -0.33 \\
\hline Gender & $-0.21^{* *}$ & -3.51 & \multicolumn{2}{|l|}{ Gender } & $-0.20 * *$ & -3.16 \\
\hline Interaction & -0.07 & -0.37 & \multicolumn{2}{|l|}{ Interaction } & -0.08 & -0.42 \\
\hline
\end{tabular}

Note. ${ }^{*} p<.05,{ }^{* *} p<.01$ (one tailed test).

egorical moderator, the variable promotion was centered and multiplied by gender to create the interaction term. Then, the variables promotion and gender were considered in the first step of the hierarchical regression and the interaction term in the second. However, there was no significant prediction of this term. Therefore, gender does not moderate the relationship between promotion and bullying. The same procedure was carried out to verify the moderation of gender in comparison with the interactive subfunction and bullying behaviors and no prediction of interaction term was found, which discards the moderator role of gender in this context.

\section{Discussion}

The aim of the study was to understand to what extent and directions the human values would correlate and predict bullying behaviors, verifying the moderating role of gender and age of respondents. We trust that this goal has been achieved. In particular, we found that the values were predictors of typical bullying behavior, which is in agreement with the results found in previous studies (Knafo, 2003; Knafo et al., 2008; Menesini et al., 2013.).

It seems clear, therefore, that the perpetrators of this type of aggression are driven by the pursuit of recognition and power, probably seeking to impose themselves by means of aggression in an attempt to be respected by their peers, assuming a position of prominence and leadership (Benish-Weisman, 2015; LaFontana \& Cillessen, 2010; Schumann et al., 2014). Children and adolescents who practice bullying are perceived by their peers as popular, so aggression can be used to achieve status and a dominant social position (de Bruyn, Cillessen, \& Wissink, 2010; Morales, Yubero, \& Larrañaga, 2016; Pouwels et al., 2016). Thus, care must be taken when promoting promotion values in a decontextualized way, as interpersonal relationships are important to take into consideration. 
As mentioned above, we found that those children who are driven by the interactive subfunction, expressed through specific affectivity values, social support and belonging, were less likely to engage in bullying behaviors. These values represent the need of belonging, love and affiliation, providing maintenance and harmony of interpersonal relationships and promoting mutual respect (Gouveia, 2003, 2013; Medeiros et al., 2012). In this sense, these values act as a protective factor for bullying behaviors, inhibiting them. Thus, it seems important to encourage the transmission of values from parents and teachers.

In this scenario, the importance of the functional theory of human values (Gouveia, 2003, 2013; Gouveia et al., 2014) to understand the main results of this study is evident. As predicted from the description of their theorized subfunctions, children at an early age are geared for success, power and prestige and are more likely to get involved in bullying situations in the role of bullies or would be more willing to assert their personal interests, imposing them upon others, which can lead to bullying behaviors at schools. We are not categorically affirming that these people will become bullies, but the importance of this subfunction is that it indicates a risk factor for such behavior. Therefore, those who seek material achievements and prefer to act in practical ways to make decisions and express behaviors are more likely to engage in discriminatory behavior and bullying is one type of behavior. In contrast, given the importance of humanitarian values, particularly social orientation, such as the interactive values, promote acceptance of others, are less discriminating, and prevent behaviors that depreciate others. Therefore, the role that values play to understand bullying seem to be clearly important, which explains the $14 \%$ of variance, a value higher than other individual predictors (e.g., internalizing [1.44\%], externalizing [11.5\%] or academic performance [4.41\%]; Cook et al., 2010).

It is evident that the two hypotheses of the study corroborate. However, it is important to note that the relationship between the values and bullying behaviors were not moderated by gender and age of the participants, as it was first suggested by empirical studies that support the role of these demographic variables for the understanding of bullying (Carlyle \& Steinman, 2007; LaFontana \& Cillessen, 2010; Sourander et al., 2000). The 10-12 year age range (77.6\% of the sample) of participants must not be disregarded, which may have been crucial for not determining any relationship with bullying. It is important that further studies consider more age heterogeneous samples as this variable shows a pattern of curvilinear correlation with bullying (Álvarez-García et al., 2015).

Further research should take into account other predictors of bullying, such as parenting styles, since the family context influences the children's first opportunities for socialization, playing a leading role in children's behavior and their interaction with others (Ribeiro, 2007). Therefore, possible exposure of children to episodes of domestic violence, often characterized by an authoritarian style, is consistent with the high risk for developing bullying behaviors as children will perceive violence as an acceptable method for resolving conflicts (Bauer et al., 2006; Bowes et al., 2009; Lucas et al., 2015). It is common that bullies have authoritarian and overprotective parents, while the victims typically have permissive parents (Baldry \& Farrington, 2000; Georgiou, 2008; Knafo, 2003).

It will also be important to test other moderators of the relationship between values and bullying behaviors. In particular, it might be found to what extent the values of the children's parents act as moderators of this relation. It could also be fit to consider that these parents support the discriminatory practice of bullying, showing discriminatory behavior in relation to minority groups (e.g., gays, overweight, etc.). Thus, several research alternatives are open to consider the values as exponents of bullying, but other exponents constructs may also be considered such as personality traits and the belief in a just world. It is possible that the naturalization of this type of aggressive behavior is more common among those with the high belief that everyone has what they deserve, that is, the world is essentially just and for that reason minority groups are discrimi- 
nated and become the object of aggression (Uhlmann, Brescoll, \& Machery, 2010).

Finally, the present study has some limitations. For example, the sample was not probabilistic, making it impossible to generalize the findings beyond the scope of the research. In addition, as self-report measures were used, this could have influenced the social desirability of the participants when answering the questionnaires. This is particularly possible because of the type of construct that is trying to be explained, i.e. bullying, which is presumably undesirable to most people.

Despite those limitations, the results indicate the important role of values for the understanding of bullying and interventions based on promoting values can contribute to the reduction of such aggressive behavior among students. In particular, a possible intervention would be the instruction of parents and teachers to promote the importance of values to the children, particularly those of a social orientation that have been consistently shown as protective factors against problematic attitudes and behaviors (Formiga \& Gouveia, 2005; Medeiros, Pimentel, Monteiro, Gouveia, \& Medeiros, 2015; Pimentel, Gouveia, Medeiros, Santos, \& Fonseca, 2011).

\section{References}

Álvarez-García, D., García, T., \& Núñez, J. C. (2015). Predictors of school bullying perpetration in adolescence: A systematic review. Aggression and Violent Behavior, 23, 126-136.

Arseneault, L., Walsh, E., Trzesniewski, K., Newcombe, R., Caspi, A., \& Moffitt, T. E. (2006). Bullying victimization uniquely contributes to adjustment problems in young children: A nationally representative cohort study. Pediatrics, 118, 130-138.

Baldry, A. C., \& Farrington, D. P. (2000). Bullies and delinquents: Personal characteristics and parental styles. Journal of Community \& Applied Social Psychology, 10, 17-31.

Bauer, N. S., Herrenkohl, T. I., Lozano, P., Rivara, F. P., Hill, K. G., \& Hawkins, J. D. (2006). Childhood bullying involvement and exposure to intimate partner violence. Pediatrics, 118, 235-242.
Bender, D., \& Lösel, F. (2011). Bullying at school as a predictor of delinquency, violence and other anti-social behaviour in adulthood. Criminal Behaviour and Mental Health, 21, 99-106.

Benish-Weisman, M. (2015). The interplay between values and aggression in adolescence: A longitudinal study. Developmental psychology, 51, 677-687.

Blank, D., \& Liberal, E. F. (2005). O pediatra e as causas externas de morbimortalidade. Jornal de Pediatria, 81, 119-122.

Bowes, L., Arseneault, L., Maughan, B., Taylor, A., Caspi, A., \& Moffitt, T. E. (2009). School, neighborhood, and family factors are associated with children's bullying involvement: A nationally representative longitudinal study. Journal of the American Academy of Child \& Adolescent Psychiatry, 48, 545-553.

Brown, T. A. (2006). Confirmatory factor analysis for applied research. New York: The Guilford Press.

Carlyle, K. E., \& Steinman, K. J. (2007). Demographic differences in the prevalence, co-occurrence, and correlates of adolescent bullying at school. Journal of School Health, 77, 623-629.

Cook, C. R., Willians, K. R., Guerra, N. G., Kim, T. E., \& Sadek, S. (2010). Predictors of bullying and victimization in childhood and adolescence: A meta-analytic investigation. School Psychology Quarterly, 25, 65-83.

Costa, M. R., Xavier, C. C., Andrade, A. C. S., Proietti, F. A., \& Caiaffa, W. T. (2015). Bullying among adolescents in a Brazilian urban center - "Health in Beagá" study. Revista de Saúde Pública, 49, 1-10.

Craig, W., Harel-Fisch, Y., Fogel-Grinvald, H., Dostaler, S., Hetland, J., Simons-Morton, B., ...Pickett, W. (2009). A cross-national profile of bullying and victimization among adolescents in 40 countries. International Journal of Public Health, 54, 216-224.

De Bruyn, E. H., Cillessen, A. H., \& Wissink, I. B. (2010). Associations of peer acceptance and perceived popularity with bullying and victimization in early adolescence. The Journal of Early Adolescence, 30, 543-566.

Del Rey, R., Lazuras, L., Casas, J. A., Barkoukis, V., Ortega-Ruiz, R., \& Tsorbatzoudis, H. (2016). Does empathy predict (cyber) bullying perpetra- 
tion, and how do age, gender and nationality affect this relationship? Learning and Individual Differences, 45, 275-281.

Farrington, D. P. (1993). Understanding and preventing bullying. In M. Tommy \& N. Morris, Crime and justice. Chicago, IL: University of Chicago Press.

Farrington, D. P., \& Ttofi, M. M. (2011). Bullying as a predictor of offending, violence and later life outcomes. Criminal Behaviour and Mental Health, 21, 90-98.

Feather, N. T. (2004). Value correlates of ambivalent attitudes toward gender relations. Personality and Social Psychology Bulletin, 30, 3-12.

Fleming, L. C., \& Jacobsen, K. H. (2009). Bullying and symptoms of depression in Chilean middle school students. Journal of School Health, 79, 130-137.

Formiga, N. S., \& Gouveia, V. V. (2005). Valores humanos e condutas anti-sociais e delitivas. Psicologia: Teoria e Prática, 7, 134-170.

Fossati, A., Borroni, S., \& Maffei, C. (2012). Bullying as a style of personal relating: Personality characteristics and interpersonal aspects of self-reports of bullying behaviours among Italian adolescent high school students. Personality and Mental Health, 6, 325-339.

Geel, M. V., Vedder, P., \& Tanilon, J. (2014). Relationship between peer victimization, cyberbullying, and suicide in children and adolescents: A meta-analysis. JAMA Pediatrics, 168, 435-442.

Georgiou, S. N. (2008). Parental style and child bullying and victimization experiences at school. Social Psychology of Education, 11, 213-227.

Gouveia, V. V. (2003). A natureza motivacional dos valores humanos: Evidências acerca de uma nova tipologia. Estudos de Psicologia (Natal), 8, 431-443.

Gouveia, V. V. (2013). Teoria funcionalista dos valores humanos: Fundamentos, aplicações e perspectivas. São Paulo, SP: Casa do Psicólogo.

Gouveia, V. V., Milfont, T. L., \& Guerra, V. M. (2014). Functional theory of human values: Testing its content and structure hypotheses. Personality and Individual Differences, 60, 41-47.

Gouveia, V. V., Milfont, T. L., Soares, A. K. S., Andrade, P. R., \& Leite, I. L. (2011). Conhecendo os valores na infância: Evidências psicométricas de uma medida. Psico, 42, 106-115.
Gouveia, V. V., Vione, K. C., Milfont, T. L., \& Fischer, R. (2015). Patterns of value change during the life span: Some evidence from a functional approach to values. Personality and Social Psychology Bulletin, 41, 1276-1290.

Hertz, M. F., Donato, I., \& Wright, J. (2013). Bullying and suicide: A public health approach. Journal of Adolescent Health, 53(Suppl.), S1-S3.

Kim, Y. S., Koh, Y. J., \& Leventhal, B. (2005). School bullying and suicidal risk in Korean middle school students. Pediatrics, 115, 357-363.

Kline, R. B. (2016). Principles and practice of structural equation modeling ( $4^{\text {th }}$ ed.). New York: Guilford Press.

Klomek, A. B., Sourander, A., \& Gould, M. (2010). The association of suicide and bullying in childhood to young adulthood: A review of crosssectional and longitudinal research findings. The Canadian Journal of Psychiatry, 55, 282-288.

Knafo, A. (2003). Authoritarians, the next generation: Values and bullying among adolescent children of authoritarian fathers. Analyses of Social Issues and Public Policy, 3, 199-204.

Knafo, A., Daniel, E., \& Khoury-Kassabri, M (2008). Values as protective factors against violent behavior in Jewish and Arab high schools in Israel. Child Development, 79, 652-667.

LaFontana, K. M., \& Cillessen, A. H. N. (2010). Developmental changes in the priority of perceived status in childhood and adolescence. Review of Social Development, 19, 130-147.

Lam, S. F., Law, W., Chan, C.-K., Wong, B. P. H., \& Zhang, X. (2014). A latent class growth analysis of school bullying and its social context: The self-determination theory perspective. School Psychology Quarterly, 30, 75-90.

Lee, C. H. (2009). Personal and interpersonal correlates of bullying behaviors among Korean middle school students. Journal of Interpersonal Violence, 25, 152-176.

Lopes, A. A., Neto. (2005). Bullying: Comportamento agressivo entre estudantes. Jornal de Pediatria, 81, 164-172.

Lucas, S., Jernbro, C., Tindberg, Y., \& Janson, S. (2015). Bully, bullied and abused. Associations between violence at home and bullying in childhood. Scandinavian Journal of Public Health, $44,1-9$. 
Lucia, S. (2016). Correlates of bullying in Switzerland. European Journal of Criminology, 13, 5066.

Malta, D. C., Porto, D. L., Crespo, C. D., Silva, M. M. A., Andrade, S. S. C., Mello, F. C. M., Monteiro, R., \& Silva, M. A. I. (2014). Bullying em escolares brasileiros: Análise da Pesquisa Nacional de Saúde do Escolar (PeNSE 2012). Revista Brasileira de Epidemiologia, 17(Supl. 1), 92-105.

Medeiros, E. D., Gouveia, V. V., Gusmão, E. E. S., Milfont, T. L., Fônseca, P. N., \& Aquino, T. A. A. (2012). Teoria funcionalista dos valores: Evidências de sua adequação no contexto paraibano. Revista de Administração Mackenzie, 13, 18-44.

Medeiros, E. D., Gouveia, V. V., Monteiro, R. P., Silva, P. G. N., Lopes, B. J., Medeiros, P. C. B., \& Silva, E. S. (2015). Escala de Comportamentos de Bullying (ECB): Elaboração e evidências psicométricas. Psico-USF, 20, 385-397.

Medeiros, E. D., Pimentel, C. E., Monteiro, R. P., Gouveia, V. V., \& Medeiros, P. C. B. (2015). Valores, atitudes e uso de bebidas alcoólicas: Proposta de um modelo hierárquico. Psicologia: Ciência e Profissão, 35, 841-854.

Melander, L. A., Hartshorn, K. J. S., \& Whitbeck, L. B. (2013). Correlates of bullying behaviors among a sample of North American Indigenous adolescents. Journal of Adolescence, 36, 675684.

Menesini, E., Nocetini, A., \& Camodeca, M. (2013). Morality, values, traditional bullying, and cyberbullying in adolescence. British Journal of Developmental Psychology, 31, 1-14.

Miles, J. N. V., \& Shevlin, M. E. (2001). Applying regression and correlation: A guide for students and researchers. London: Sage.

Morales, J. F., Yubero, S., \& Larrañaga, E. (2016). Gender and bullying: Application of a three-factor model of gender stereotyping. Sex Roles, 74, 169-180.

Nansel, T. R., Overpeck, M., Pilla, R. S., Ruan, W. J., Simons-Morton, B., \& Scheidt, P. (2001). Bullying behaviors among US youth: Prevalence and association with psychosocial adjustment. Jama, 285, 2094-2100.

Oliveira, W. A., Silva, M. A. I., Silva, J. L., Mello, F. C. M., Prado, R. R., \& Malta, D. C. (2016). Associações entre a prática do bullying e variá- veis individuais e de contexto na perspectiva dos agressores. Jornal de Pediatria, 92, 32-39.

Olweus, D. (1993). Bullyng at school: What we know and what we can do. Cambridge, MA: Blackwell.

Perren, S., \& Alsaker, F. D. (2006). Social behavior and peer relationships of victims, bully-victims, and bullies in kindergarten. Journal of Child Psychology and Psychiatry, 47, 45-57.

Pimentel, C. E., Gouveia, V. V., Medeiros, E. D., Santos, W. S., \& Fonseca, P. N. (2011). Explicando atitudes frente à maconha e comportamentos antissociais: O papel dos valores e grupos normativos. In S. C. S. Fernandes, C. E. Pimentel, V. V. Gouveia, \& J. L. A. Estramiana (Eds.), Psicologia social: Perspectivas atuais e evidências empíricas (pp. 13-23). São Paulo, SP: Casa do Psicólogo.

Pouwels, J. L., Lansu, T. A., \& Cillessen, A. H. (2016). Participant roles of bullying in adolescence: Status characteristics, social behavior, and assignment criteria. Aggressive Behavior, 42, 239-253

R Core Team. (2015). R: A language and environment for statistical computing. Vienna, Austria: $\mathrm{R}$ Foundation for Statistical Computing. Retrieved from http://www.R-project.org/

Reed, K. P., Nugent, W., \& Cooper, R. L. (2015). Testing a path model of relationships between gender, age, and bullying victimization and violent behavior, substance abuse, depression, suicidal ideation, and suicide attempts in adolescents. Children and Youth Services Review, 55, 128-137.

Ribeiro, A. T. M. (2007). O bullying em contexto escolar: Estudo de caso (Unpublished master's thesis, Universidade Portucalense, Porto, Portugal).

Roh, B. R., Yoon, Y., Kwon, A., Oh, S., Lee, S. I., Ha, K., ...Hong, H. J. (2015). The structure of co-occurring bullying experiences and associations with suicidal behaviors in Korean adolescents. PloS one, 10, 1-14.

Rosseel, Y. (2012). lavaan: An R Package for Structural Equation Modeling. Journal of Statistical Software, 48, 1-36.

Salmivalli, C. (2010). Bullying and the peer group: A review. Agression and Violent Behavior, 15, $112-120$ 
Schwartz, S. H. (1992). Universal in the content and structure of values: Theoretical advances and empirical tests in 20 countries. In M. P. Zanna (Ed.), Advanced in experimental social psychology (pp. 1-65). New York: Academic Press.

Smith, P. K., \& Morita, Y. (1999). The nature of school bullying: A cross-national perspective. London: Routledge.

Sourander, A., Hestelä, L., Helenius, H., \& Piha, J. (2000). Persistence of bullying from childhood to adolescence - A longitudinal 8-year followup study. Child Abuse \& Neglect, 24, 873-881.

Sourander, A., Jensen, P., Rönning, J. A., Elonheimo, H., Niemela, S., Helenius, H., Kumpulainen, K., ...Almqvist, F. (2007). Childhood bullies and victims and their risk of criminality in late adolescence. Archives of Pediatrics \& Adolescent Medicine, 161, 546-552.

Schumann, L., Craig, W., \& Rosu, A. (2014). Power differentials in bullying: Individuals in a community context. Journal of Interpersonal Violence, 29, 846-865.
Tani, F., Greenman, P. S., Schneider, B. H., \& Fregoso, M. (2003). Bullying and the big five: A study of childhood personality and participant roles in bullying incidents. School Psychology International, 24, 131-146.

Uhlmann, E. L., Brescoll, V. L., \& Machery, E. (2010). The motives underlying stereotypebased discrimination against members of stigmatized groups. Social Justice Research, 23, $1-16$.

Wang, J., Iannotti, R. J., \& Nansel, T. R. (2009). School bullying among adolescents in the United States: Physical, verbal, relational and cyber. Journal of Adolescent Health, 45, 368-375.

Recebido: 16/02/2016

$1{ }^{a}$ revisão: $24 / 05 / 2016$

$2^{a}$ revisão: $17 / 06 / 2016$

$2^{a}$ revisão: $11 / 07 / 2016$

Aceite final: 12/07/2016 